\title{
Taxonomic redefining of Pyramidula jaenensis (Clessin, 1882) (Gastropoda: Pyramidulidae) based on an integrative taxonomy approach
}

\author{
J.P. Miller', F. García-Guerrero'1, A.A. Rodríguez Sousa², \\ M. Carrillo Pacheco ${ }^{3}$
}

\begin{abstract}
${ }^{I}$ Museo Nacional de Ciencias Naturales - CSIC, C/ José Gutiérrez Abascal, 2, 28006, Madrid, Spain.E-mail: jonathanmiller@mncn.csic.es,f.garciaguerrero@mncn.csic.es

${ }^{2}$ Department of Biology and Geology, Physics and Inorganic Chemistry, Biodiversity and Conservation Area, School of Experimental Sciences and Technology (ESCET URJC), University Rey Juan Carlos. C/ Tulipán s/n, 28933 Madrid, Spain.E-mail: antonioalberto.sousa@urjc.es

${ }^{3}$ Independent researcher, Madrid, Spain.E-mail: mcarrill@telefonica.net
\end{abstract}

\begin{abstract}
The genus Pyramidula presents a Palearctic geographical distribution, being described in Spain four species not distinguishable from an anatomical point of view. In the present study, we compare our samples along with the previously recognized species $P$. rupestris, $P$. saxatilis, $P$. pusilla, $P$. cephalonica; $P$. jaenensis, and $P$. chorismenostoma by means of molecular studies. Also, we compared $P$. jaenensis from the studied locality with $P$. rupestris according to the shell shape by means of geometric morphometric methods. The analysis of the Thin-Plate Spline graph showed that $P$. jaenensis presented an expansion on the growth to the first whorls and the apex, whereas the height of the body whorl was moderately contracted, while in P. rupestris the opposite was found. We found significant differences between both species based on shell shape. We also provide new information about morphological features that could be used in future studies of this genus attempting to stablish a baseline to test whether the Spanish species are cryptic species or not. The present study also extends the distribution of Pyramidula to Madrid, Spain, establishing for the first time the presence of $P$. jaenensis in this Spanish province.

How to cite this article: Miller J.P., García-Guerrero F., Rodríguez Sousa A.A., Carrillo Pacheco M. 2021. Taxonomic redefining of Pyramidula jaenensis (Clessin, 1882) (Gastropoda: Pyramidulidae) based on an integrative taxonomy approach // Invert. Zool. Vol.18. No.4. P.465-480. doi: 10.15298/invertzool.18.4.04
\end{abstract}

KEY WORDS: Pyramidula, Geometric Morphometric, Taxonomy, Land snails, Malacology, Molecular data, Polymerase Chain Reaction (PCR), Madrid.

\section{Таксономическое переопределение Pyramidula} jaenensis (Clessin, 1882) (Gastropoda: Pyramidulidae), основанное на интегративном таксономическом подходе

\section{Дж.П. Миллер ${ }^{1}$ Ф. Гарсия-Гуерреро', А.А. Родригез Соуса², М. Каррилло Пачеко ${ }^{3}$}

${ }^{1}$ Museo Nacional de Ciencias Naturales - CSIC, C/ José Gutiérrez Abascal, 2, 28006, Madrid, Spain.E-mails: jonathanmiller@mncn.csic.es,f.garciaguerrero@mncn.csic.es 
${ }^{2}$ Department of Biology and Geology, Physics and Inorganic Chemistry, Biodiversity and Conservation Area, School of Experimental Sciences and Technology (ESCET URJC), University Rey Juan Carlos.C/ Tulipán s/n, 28933 Madrid, Spain.E-mail: antonioalberto.sousa@urjc.es

${ }^{3}$ Independent researcher, Madrid, Spain.E-mail: mcarrill@telefonica.net

РЕЗЮМЕ: Географическое распространение представителей рода Pyramidula приурочено к Палеарктике. На территории Испании описано четыре вида рода, которые неотличимы по анатомическим признакам. В настоящем исследовании мы, используя методы молекулярной филогении, сравниваем взятые нами пробы и имеющиеся данные по видам P. rupestris, P. saxatilis, P. pusilla, P. cephalonica; P. jaenensis, and P. chorismenostoma. Мы также используем методы геометрической морфометрии для сравнения формы раковин у $P$. jaenensis из исследованной локации с совместно обитающей P. rupestris. TPS анализ показал, что P. jaenensis характеризуется расширением при формировании первого оборота и вершины завитка раковины, тогда как высота последнего оборота умеренно уменьшается. У P. rupestris была обнаружена противоположная картина роста раковины . Мы обнаружили существенные различия в форме раковины у двух изученных видов: P. jaenensis и P. rupestris. В ходе работы была получена новая информация о деталях морфологического строения исследованных видов, которая может быть использована в дальнейшем анализе для решения вопроса о том могут ли виды рода, обитающие на территории Испании быть названы криптическими. Настоящее исследование позволяет расширить представления об ареале распространения рода Pyramidula, поскольку вид P. jaenensis впервые обнаружен в окрестностях Мадрида.

Как цитировать эту статью: Miller J.P., García-Guerrero F., Rodríguez Sousa A.A., Carrillo Pacheco M. 2021. Taxonomic redefining of Pyramidula jaenensis (Clessin, 1882) (Gastropoda: Pyramidulidae) based on an integrative taxonomy approach // Invert. Zool. Vol.18. No.4. P.465-480. doi: 10.15298/invertzool.18.4.04

KEY WORDS: Pyramidula, геометрическая морфометрия, таксономия, наземные улитки, малакология, молекулярно-генетический анализ, ПЦР, Мадрид.

\section{Introduction}

The land snail genus Pyramidula Fitzinger, 1833 is mainly distributed in Europe, Mediterranean area, Central Asia and Japan, inhabiting limestone rocks from elevations ranging from sea level to 3800 m.a.s.l (Schileyko, Balashov, 2012; Razkin et al., 2017). In Spain four species had been described, P.jaenensis (Clessin, 1882) occurring mainly to the South and East and $P$. pusilla (Vallot, 1801), P. rupestris (Draparnaud, 1801 and $P$. umbilicata (Montagu, 1803) occurring mainly to the North. According to Martínez-Ortí et al. (2007), peninsular species cannot be distinguished by the analysis of its genitalia due to the anatomical simplicity. In spite of this, in other European species, this does not happen (see Mylonas, 1982; Schileyko, Balashov, 2012). To make it more complex, sympatric distribution had been mentioned for several species (Razkin et al., 2017). This, along with the species identification based only on shell characters (e.g., Gittenberger, Bank, 1996; Martínez-Ortí et al., 2007) makes the taxonomy of this group a jigsaw, leading to the idea that Pyramidula is a cryptic species complex (Razkin et al., 2017).

The Autonomous Community of Madrid, located at the centre of the Iberian Peninsula comprises an area of ca $8000 \mathrm{~km}^{2}$ that presents high complexity in terms of landscape and geology (Karampaglidis et al., 2015). To the north, we can find the highest elevation, and series of Paleozoic granitic and metamorphic bedrocks 


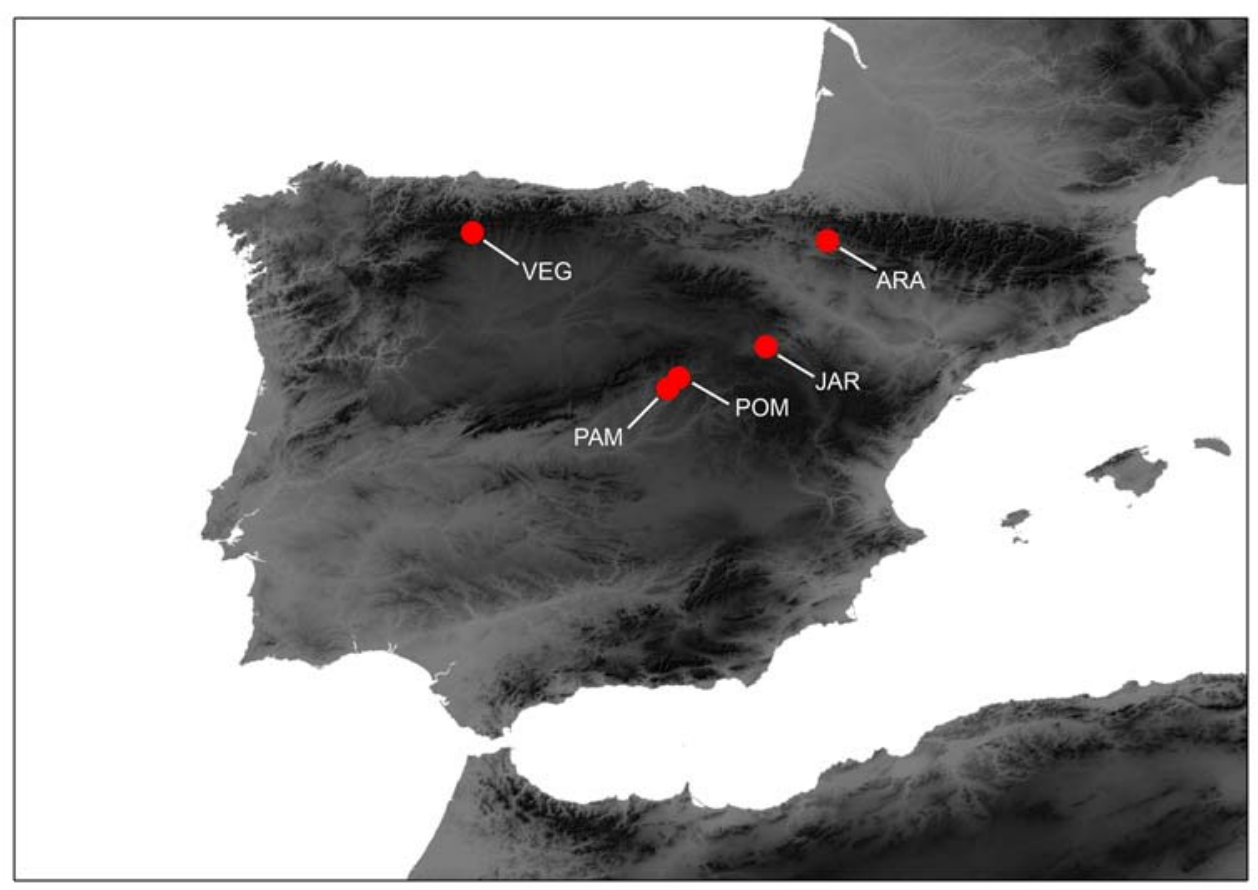

Fig. 1. Map of the studied populations of Pyramidula spp. in Spain. VEG - Vegacervera, León, Spain; JAR — Jaraba, Aragón; ARA — Arañones, Aragón; PAM — Patones, Madrid; POM — Pontón de la Oliva, Madrid.

Рис. 1. Карта, показывающая локализацию исследованных популяций видов рода Pyramidula в Испании. VEG — Vegacervera, León, Spain; JAR — Jaraba, Aragón; ARA — Arañones, Aragón; PAM — Patones, Madrid; POM — Pontón de la Oliva, Madrid.

with a transition to a plateau relief formed by depositional blocks of evaporitic rocks, sand rocks, clays and loams with scarce carbonate shelves (Yagüe, 1979).

The presence of carbonates and the availability of calcium is a necessary condition for a good development of land snail communities basically because the shell is mostly composed of calcium carbonate, and it is essential for reproduction and other physiological processes (Welter-Schultes, Williams, 1999; Hotopp, 2002; Juřičková et al., 2008).

Due to this, the species richness of molluscs on Madrid could be determined by those zones with an appropriate level of calcium, which according to Allas et al. (2001), are located more to the south, and at some limestone chunks surrounded by the metamorphic-granitic bedrocks to the north.
Despite this panorama, Aparicio (2006) cited a diversity of 47 species and 18 families of molluscs within Madrid, undoubtedly surpassed by many other regions of Spain. So, studies that reveal the presence of new species in Madrid, will be interesting for malacology in general, at the time that increases the diversity of this region.

Recent studies have revealed the phylogenetic relationship of most of the European species of the genus and also provided a framework for future identifications, and species delimitation based on molecular data $(\mathrm{COI}+16 \mathrm{~S})$ applying the phylogenetic species concept. It's noteworthy that the shell characters used to define Pyramidula through the morphological species concept is not reliable (Razkin et al., 2016, 2017). Nevertheless, anatomical studies still are needed to redefine the species based on integrative taxonomy. 
Table 1. List of the material used for this study.

Таблица 1. Материал, использованный в работе.

\begin{tabular}{lccll}
\hline \multicolumn{1}{c}{ Sample } & Species & \multicolumn{1}{c}{ Date } & \multicolumn{1}{c}{ Locality } & Collectors* \\
\hline JPM-246 & P. jaenensis & $06 / 01 / 2020$ & $\begin{array}{l}\text { Pontón de la Oliva, } \\
\text { Madrid. Spain }\end{array}$ & JPM, GCG \\
\hline JPM-247 & P. jaenensis & $06 / 01 / 2020$ & $\begin{array}{l}\text { Pontón de la Oliva, } \\
\text { Madrid. Spain }\end{array}$ & JPM, GCG \\
\hline JPM-248 & P. jaenensis & $06 / 01 / 2020$ & $\begin{array}{l}\text { Pontón de la Oliva, } \\
\text { Madrid. Spain }\end{array}$ & JPM, GCG \\
\hline JPM-170 & P. jaenensis & $24 / 03 / 2019$ & Patones, Madrid. Spain & JPM, MCP \\
\hline JPM-201 & P. jaenensis & $01 / 11 / 2019$ & $\begin{array}{l}\text { Pontón de la Oliva, } \\
\text { Madrid. Spain }\end{array}$ & $\begin{array}{l}\text { JPM, MCP, } \\
\text { GCG }\end{array}$ \\
\hline JPM-425 & P. rupestris & $14 / 09 / 2020$ & $\begin{array}{l}\text { Vegacervera, León, } \\
\text { Spain }\end{array}$ & JPM \\
\hline JPM-200 & P. rupestris & $10 / 04 / 2019$ & Jaraba, Aragon.Spain & JPM, FGG \\
\hline JPM-301 & P. rupestris & $03 / 11 / 2018$ & $\begin{array}{l}\text { Jaraba, Aragon.Spain } \\
\text { JPM, MCP, }\end{array}$ & JMR \\
\hline $\begin{array}{l}\text { MNCN } \\
15.15 / 25310\end{array}$ & P. jaenensis & & Ubeda, Jaen, Spain & \\
\hline $\begin{array}{l}\text { MNCN } \\
15.15 / 25033\end{array}$ & P. pusilla & & $\begin{array}{l}\text { Arañones, Aragon, } \\
\text { Spain }\end{array}$ & FAM \\
\hline
\end{tabular}

* JPM — Jonathan P. Miller; MCP — Miguel Carrillo Pacheco; FGG — Fernando García Guerrero; GCG — Gerson Cárdenas García; JMR — José María Requena; FAM — Florentino Azpeitia Moros.

On this work we aim to taxonomically redefine $P$. jaenensis on the basis of molecular and morphological data, using geometric morphometrics to best characterize the shell shape, joining all these sources of information to provide a general characterization for the species by means of an integrative taxonomy approach. At the same time, we extend the distribution of Pyramidula within the Autonomous Community of Madrid, Spain, mentioning for the first time the presence of $P$. jaenensis for the region.

\section{Material and Methods}

Two populations were found in Madrid, Spain (Fig. 1) collected during 2018-2020 (Table 1) in the isolated outcrops of calcareous rocks present in the area. In order to compare these populations with other species of the genus, we incorporated to the study samples from the type locality for the $P$. jaenensis. We also included the species $P$. rupestris and $P$. pusilla being some of the material, dry, from the Na- tional Museum of Natural History, Spain collection (Table 1).

The animals were drowned in water for $24 \mathrm{~h}$ and then fixed using Bouin (saturated picric acid, formaldehyde, and acetic acid solution), except for those designated to molecular studies, that were directly stored in ethanol $96 \%$. Posteriorly from the Bouin solution, they were transferred to ethanol $80 \%$ and stored at room temperature. The fixation with Bouin solution helps to maintain cellular structure for future histological studies, also it gives consistency to the tissues in order to dissect the animals.

The shells of the samples designated for anatomical dissection were removed using a decalcifying 5\% aqueous dilution of ethylenediaminetetracetic acid (EDTA). Anatomical characters and terminology will be followed as proposed by Schileyko (1998) for the genus.

\section{Molecular species identification}

Primary species identification was conducted using the phylogenetic species concept (El- 
dredge, Cracraft 1980; Cracraft, 1983), as previous studies for this genus have provided consistent multilocus phylogenies (Razkin et al., 2017) recording all the sequenced material on GenBank where it is available for other molecular studies. In our case, the lack of fresh samples reduced the scope of the research, including only $P$.jaenensis and $P$. rupestris. $P$. pusilla was not previously validated by any molecular data.

Due to the small size of the animals, DNA was extracted using the whole body. Nine individuals were analysed, corresponding to $\mathrm{Pa}$ tones (3), Jaraba (3) and Vegacervera (3). Isolation was conducted using a DNeasy Blood and Tissue kit (QIAGEN, Hilden, Germany). For DNA amplification Cytochrome Oxidase I(COI) was used with the following primers: LCOI1490 (Folmer et al., 1994) and COR722b (Wilke et al., 2000).

PCR was realized under the following conditions: each tube contained $1 \mu \mathrm{DNA}, 2.5 \mu \mathrm{l}$ of 10x Buffer, $0.6 \mu \mathrm{l}$ dNTPs mix, $0.25 \mu 1 \mathrm{MgCl}_{2}$ $25 \mathrm{mM}$ solution, 0.6 of each primer $(10 \mathrm{mM})$, $0.4 \mu 1$ Taq DNS polymerase ( $5 \mathrm{U} / \mu 1$ - Takara) and $17 \mu \mathrm{l}$ purified distilled water. The cycling conditions were $94^{\circ} \mathrm{C}$ for $4 \mathrm{~min}$, one cycle; $94^{\circ} \mathrm{C}$ for $45 \mathrm{secs}, 48{ }^{\circ} \mathrm{C}(\mathrm{COI}), 72{ }^{\circ} \mathrm{C}$ for $45 \mathrm{secs}, 35$ cycles; $72^{\circ} \mathrm{C}$ for $10 \mathrm{~min}$ for the final extension, after that kept at $4^{\circ} \mathrm{C}$.

One microlitre of the PCR product was analysed to determine the quantity of DNA obtained from the PCR. It was verified using $1 \%$ agarose gel with SYBR Safe (Invitrogen, USA) to visualize it under UV light. After that $10 \mu \mathrm{l}$ of the PCR product was cleaned using EXOSAP (ThermoFisher, USA), and then $5 \mu \mathrm{l}$ of PCR product plus primer ( $5 \mathrm{mM}$ - Forward and Reverse) were sequenced at Macrogen (Macrogen, Korea) based in Madrid.

The sequences, previously obtained, were edited using SEQUENCHER v.5.4.6 (Gene Codes, Ann Arbor, MI, USA). Sequences available from Genbank (Clark et al., 2016) were downloaded using R 3.5.3 (Core-Team, 2017) with the ape (Paradis, Schliep, 2018), seqinr (Charif, Lobry, 2007) and rentrez (Winter, 2017) packages. Posteriorly, all the sequences were aligned manually using MEGA v.7.0.14 (Kumar et al., 2016) and the species Orcula dolium (Draparnaud, 1801) was used as outgroup.

The Bayesian Inference (BI) analysis was conducted using Markov chain Monte Carlo (MCMC) sampling in MrBayes v3.2.2 (Huelsenbeck, Ronquist, 2001; Ronquist, Huelsenbeck, 2003) for $20 \times 10^{6}$ generations, four parallel chains, sampling a tree every 1000 generations. The first $10 \%$ of the sampled trees were discarded as burn-in. The convergence of the chain was monitored by ensuring a standard deviation of the split frequency $<0.01$. The Bayesian posterior probabilities (BPPs) were used as a measure of the robustness of the inferred tree. The branch supports as well as all the tree editing were done with FigTree v.1.4.3 (Rambaut, 2012).

The Maximum Likelihood (ML) analyses were computed using RAxML-HCP v.8 (Stamatakis, 2014) through The Cyber Infrastructure for Phylogenetic Research - CIPRES (Miller et al., 2010), using the GTR (Tavaré, 1986) + I + ̃̃ model. A non-parametric bootstrapping was assessed to determine the robustness of the analyses and the majority-rule criterion was selected to indicate the program to halt bootstrapping automatically.

\section{Geometric morphometrics of the shell}

All the pictures and measures were taken using a Leica MZ16 stereomicroscope with a Leica DFC550 camera using the Leica Application Suite (LAS) V4.6. For Geometric Morphometric (GM) analysis a total of 212 shells were photographed, corresponding to $P$. rupestris (70), P.jaenensis (114) and P. pusilla (28). The last species was included in the GM analysis but as it comes from a museum collection, we assumed a correct identification of the sample. The rest of the localities used for GM, were previously identified in the molecular section.

In order to extract the information about the shape of the shell, a total of five landmarks and 13 semi landmarks were placed (Fig. 2). The data with the coordinates were subjected to a Procrustes superimposition (Gower, 1975) as a way of removing the effect of size, orientation and position from the information gathered by 


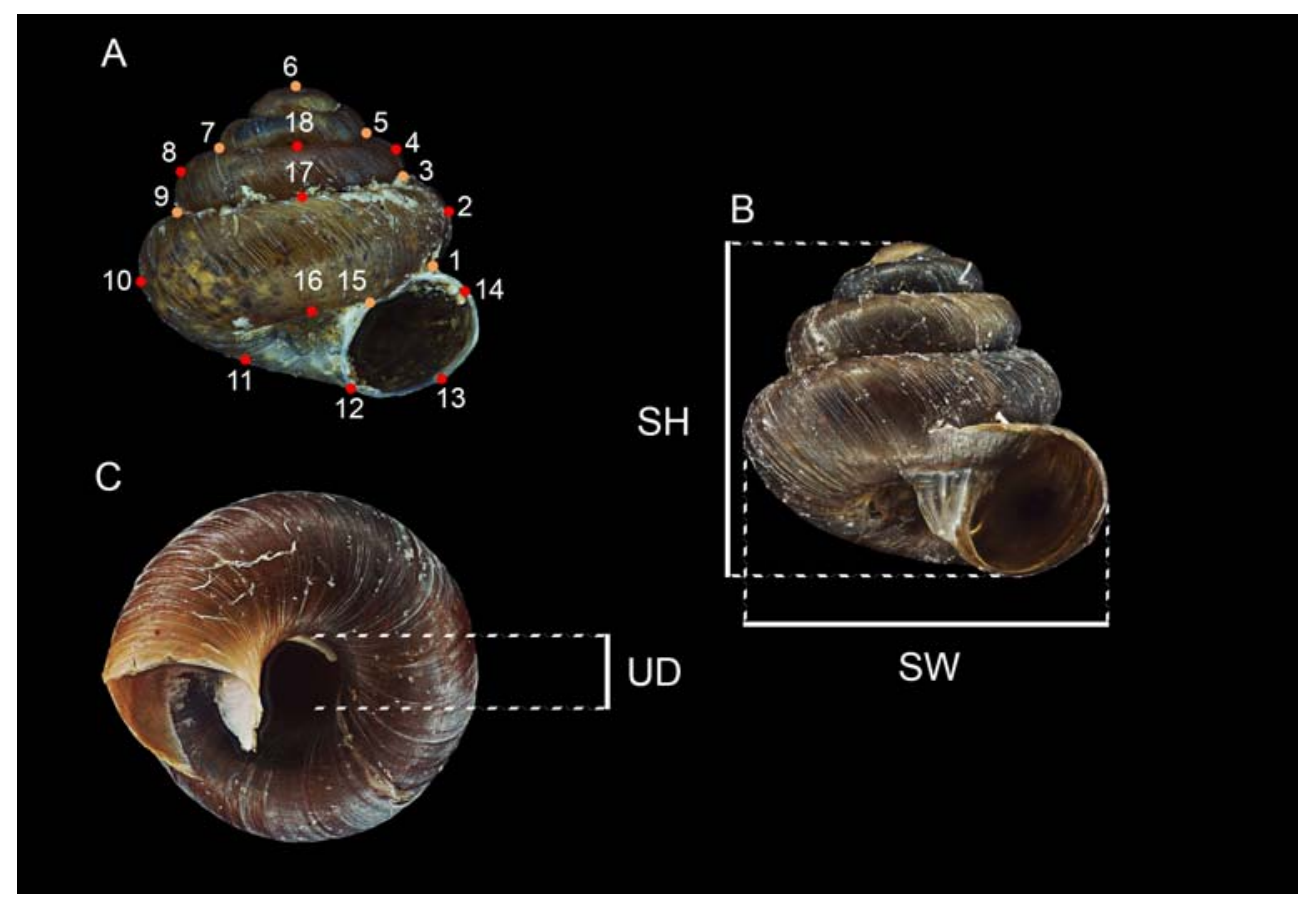

Fig. 2. A - configuration of landmarks (orange dots) and semilandmarks (red dots) used for the geometric morphometric analysis; B-C - measures used for conchological comparisons.

Abbreviations: SH - shell hight; SW — shell width; UD - umbilicus diameter.

Fig. 2. A - позиционирование меток (рыжие точки) и полуметок (красные точки), использованных для геометрического морфометрического анализа; B-C - промеры, использованные для сравнения формы раковины

Сокращения: SH — высота раковины; SW — ширина раковины; UD — диаметр пупка.

the landmark's configurations. As a mean to plot the morphological similarity among species a Principal Component Analysis (PCA) was performed (Jolliffe, 2002). The analyses were conducted using PAST v.3.0 (Hammer et al., 2020) and TPSdig 2.0 (Rohlf, 2006).

Differences between species were tested using a PERMANOVA analysis with adjustment of Euclidean distance (Anderson, 2005). This is a non-parametric analysis used to perform a comparison between groups instead of using parametric methods. In this case, the algorithm tests the significance utilizing permutations of distance matrices, being the significance criterion $\mathrm{p}<0.05$.

The PERMANOVA method could be affected by the effect of the dispersion in the data cloud (Anderson, Walsh, 2013), thus we performed a test for homogeneity of multivariate dispersions (PERMDISP, Anderson, 2014) over the same dataset to test the homoscedasticity of the data. These analyses were conducted using R v.4.0.0 (Core-Team, 2017) statistical environment using the vegan package (Oksanen et al., 2013) and for both analyses, 999 replicates.

ABBREVIATIONS: SH - Shell length; SW — Shell width; UD — Umbilicus diameter; $\mathrm{CV}$ - Coefficient of variation; Max — Maximum; Min — Minimum; bp — Base pairs.

\section{Results}

The cytochrome oxidase I dataset covered a total of six species of Pyramidula, yielding a matrix of 655 bp. By both BI and ML P. rupestris, $P$. saxatilis, $P$. pusilla, and $P$. cephalonica (Westerlund, 1898), as well as the relation among them, were well supported ( $p>0.95$, and boos- 


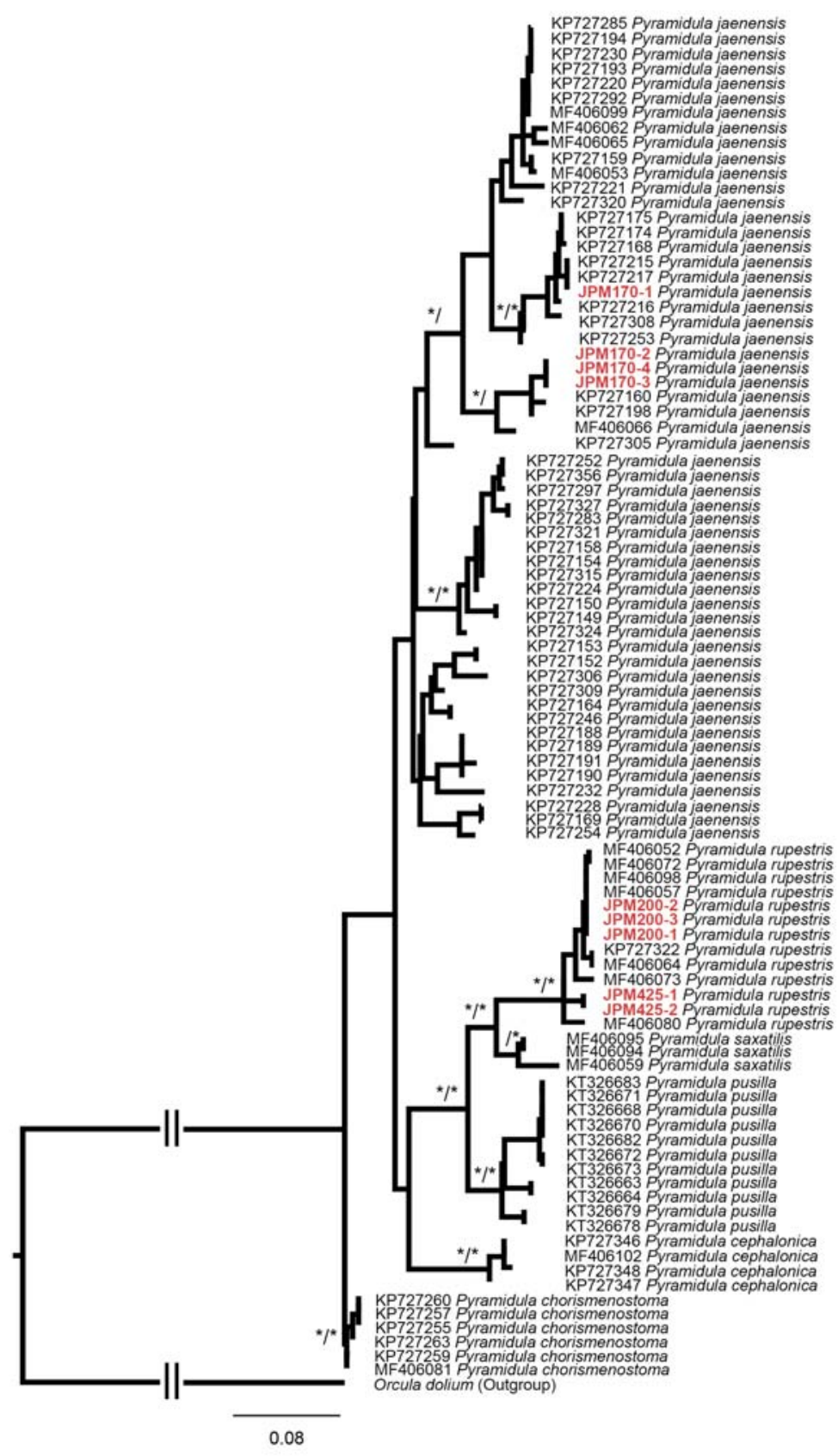

Fig. 3. Phylogenetic relationships of Pyramidula spp. inferred by maximum likelihood (ML) and Bayesian Inference (BI) analyses of the COI.

Bootstrap and/or Bayesian posterior probability supports $>75 \%$ and $>0.95$, respectively, are shown above the species level (topology of the tree from ML analysis) indicated with "**". Sequences obtained in this study are shown in red. Рис. 3. Схема филогенетических отношений Pyramidula spp. полученная методами максимального правдоподобия (ML) и Байесовским анализом (BI) для COI.

Бутстрэп и/или Байесовская апостериорная вероятность на уровне $>75 \%$ и $>0.95$, соответственно, обозначены «*» выше видового уровня (топология дерева из анализа ML). Сиквенсы, полученные для этого исследования, выделены красным. 
Table 2. Uncorrected pairwise distances (percentages) among COI sequences from Pyramidula species. Таблица 2. Некорректированные попарные расстояния (\%) между сиквенсами.

\begin{tabular}{lllllllll}
\hline & & & $\mathbf{1}$ & $\mathbf{2}$ & $\mathbf{3}$ & $\mathbf{4}$ & $\mathbf{5}$ & $\mathbf{6}$ \\
\hline $\mathbf{1}$ & P. cephalonica & - & & & & & & \\
\hline $\mathbf{2}$ & P. jaenensis & 9.2 & - & & & & \\
\hline $\mathbf{3}$ & P. rupestris & 10.2 & 10.9 & - & & & \\
\hline $\mathbf{4}$ & P. saxatilis & 8.5 & 8.4 & 5.3 & - & & \\
\hline $\mathbf{5}$ & P. chorismenostoma & 7.0 & 7.4 & 8.5 & 6.8 & - & \\
\hline $\mathbf{6}$ & P. pusilla & 9.2 & 9.7 & 7.0 & 5.9 & 8.4 & - \\
\hline
\end{tabular}

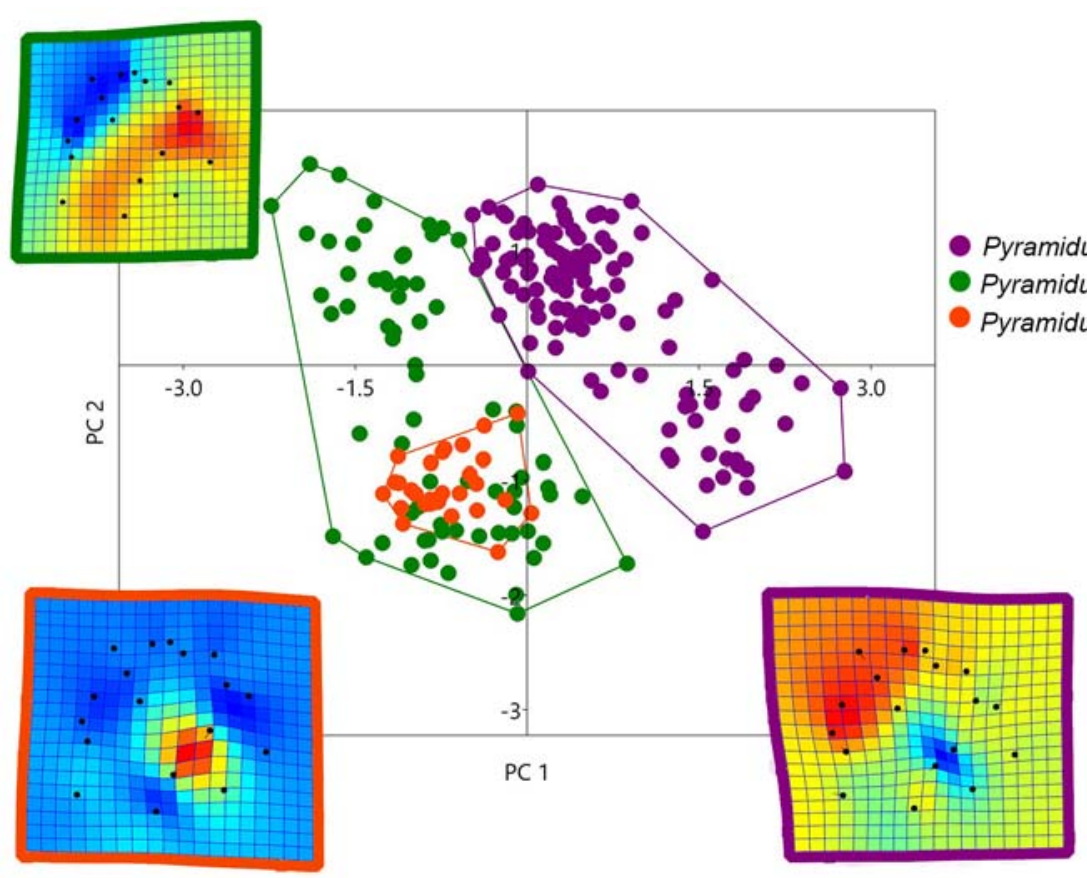

Fig. 4. Morphological similitude between $P$. jaenensis, $P$. rupestris and $P$. pusilla according to the shell shape, with 18 landmarks. Thin-Plate Spline shows deformation of the consensus of each species against the mean shape, red colour shows expansion while blue colour shows contraction.

Рис. 4. Морфологическое подобие между P. jaenensis, P. rupestris и P. pusilla согласно анализу формы раковины по 18 меткам. Thin-Plate Spline показывает деформации усредненных конфигураций для каждого вида против усредненной формы, красным цветом показано расширение, синим цветом показано сжатие.

trap $>75 \%$ ), while for $P$. jaenensis and $P$. chorismenostoma (Westerlund, Blanc, 1879) the relation with the other congeners was not supported by any of the analysed methods (Fig. 3 ). The genetic distance between species based on the uncorrected pairwise distance among COI sequences ranged from 5.3 and $10.9 \%$
(Table 2). Samples from Jaraba, Aragon, Spain and Vegacervera, León, Spain (Fig. 3, coded as JPM425-1,2 and JPM200-1,2,3) were found to cluster with $P$. rupestris, while samples from Patones, and Pontón de la Oliva, Madrid, Spain (Fig. 3, coded as JPM170-1 to JPM170-4) clustered with $P$. jaenensis. 
A total of 212 pictures from six localities were analysed, scoring the morphological similarity among species of Pyramidula based on the GM analysis of the shell shape. The PCA (Fig. 4) accounted in the first two components a total $64.9 \%$ of the shell shape variation, and including the third component the accounted variation was the $71.9 \%$ of the shell shape variation. The first three components can differentiate between $P$. rupestris and $P$. jaenensis, nevertheless, the samples labelled as $P$. pusilla, proceeding from Arañones, Canfranc, Spain clustered with $P$. rupestris. The included topotypes of $P$. jaenensis were found to cluster with the samples from Madrid.

The analysis of the Thin-Plate Spline graph showed that $P$. jaenensis presented an expansion on the growth to the first whorls and the apex, while the height of the body whorl was moderately contracted, while in $P$. rupestris the opposite was found, a major expansion factor to the body whorl and compression to the first whorls and apex. In P. pusilla we found only an expansion factor to the centre of the body whorl (Fig. 4).

The PERMANOVA test showed overall statistical significance $(\mathrm{p}$-value $=0.0001, \mathrm{~F}=$ 81.077 ) and the pairwise comparison determined statistical differences between $P$. jaenensis and $P$. rupestris (p-value $=0.003, \mathrm{R}^{2}=0.36$ ); $P$. jaenensis and $P$. pusilla $\left(\mathrm{p}\right.$-value $=0.003, \mathrm{R}^{2}=$ $0.33)$; $P$. rupestris and $P$. pusilla (p-value $=$ $0.012, \mathrm{R}^{2}=0.05$ ). Despite these results, the PERMDISP was also significant ( $\mathrm{p}$-value $=$ $0.001, \mathrm{~F}=33.011$ ) depicting significant dispersion on the dataset.

\section{Systematics}

Class Gastropoda Cuvier, 1795

Subclass Heterobanchia Burmeister, 1837

Order Stylommatophora Schmidt, 1855

Superfamily Pupilloidea W. Turton, 1831

Family Pyramidulidae Kennard et B.B.

Woodward, 1914

Pyramidula jaenensis (Clessin, 1882)

Helix (Patula) jaenensis Clessin, 1882: 187 185.

Pyramidula rupestris var. jaenensis: Pilsbry, 1935:

Pyramidulajaenensis: Ortiz de Zárate Rocandio, Ortiz de Zárate López, 1961: 189. 73.

Pyramidula jaenensis: Gittenberger, Bank, 1996: 72

Pyramidula jaenensis: Martínez-Ortí et al., 2007: 78. Pyramidula jaenensis: Razkin et al., 2017: 67-68.

MATERIAL EXAMINED: see Table 1.

TYPE LOCALITY: according to the original description: "Jaen, Hispaniae"Clessin(1882: 187)

DESCRIPTION: Shell conical-turbinate, moderately thin-walled, 4-5 whorls, each whorl with convex sides. Shell higher than broad, or about equal in high and breadth (Fig. 5A-E). Shell dimensions as follow: $\mathrm{SH}=2.21 \pm 0.28$ $\mathrm{mm} ; \mathrm{CV}=0.13$ (Max: $3.02 \mathrm{~mm}-$ Min: $1.7 \mathrm{~mm}$ ); $\mathrm{SW}=2.19 \pm 0.2 \mathrm{~mm} ; \mathrm{CV}=0.09($ Max: 2.91 $\mathrm{mm}-$ Min: $1.84 \mathrm{~mm}) ; \mathrm{UD}=0.52 \pm 0.11 \mathrm{~mm} ; \mathrm{CV}$ $=0.21($ Max: $0.88 \mathrm{~mm}-$ Min: $0.4 \mathrm{~mm}) ; \mathrm{SH} / \mathrm{SW}$ $=1.01 \pm 0.07 ; \mathrm{CV}=0.07$ (Max: $1.18-\mathrm{Min}$ : $0.85)$; $\mathrm{UD} / \mathrm{SW}=0.24 \pm 0.04 ; \mathrm{CV}=0.17$ (Max: 0.31 - Min: 0.18); $\mathrm{N}=55$ (Measured samples from Patones, Madrid and Pontón de la Oliva, Madrid). Protoconch with $1 \frac{1}{2}$ whorls (Fig. 5K, O). Sculpture rugose at the embryonic shell, changing gradually to radially striated at the teleoconch; irregular and poorly marked striae. Aperture oval, with cutting simple margins. Umbilicus wide and perspective, measuring about $1 / 4$ of the shell's total width (Fig. 5L). Colour dark corneous to brownish.

Animal dark pigmented. Reproductive system hermaphroditic and ovoviviparous. Penis small, gradually tapering from the penial caecum to the epiphallus presenting an arrow shape (Fig. 6E). Penial caecum broader than the penis, poorly developed; epiphallus longer than the penis, presenting a thickening at the junction with the vas deferens. Reservoir triangular to pyriform lying on the upper half of the uterus, presenting a whitish amorphous substance, without diverticulum; spermathecal duct, long, thin, about 4 times the reservoir length. Vagina ca. 3.5-4 times longer than the penis, in fertilized specimens containing well-developed embryos.

Radula containing ca. 170 anteriorly pointed $\mathrm{V}$-shaped rows, each row contains about 25 teeth; radula formula 6-7-1-7-6; Central tooth 


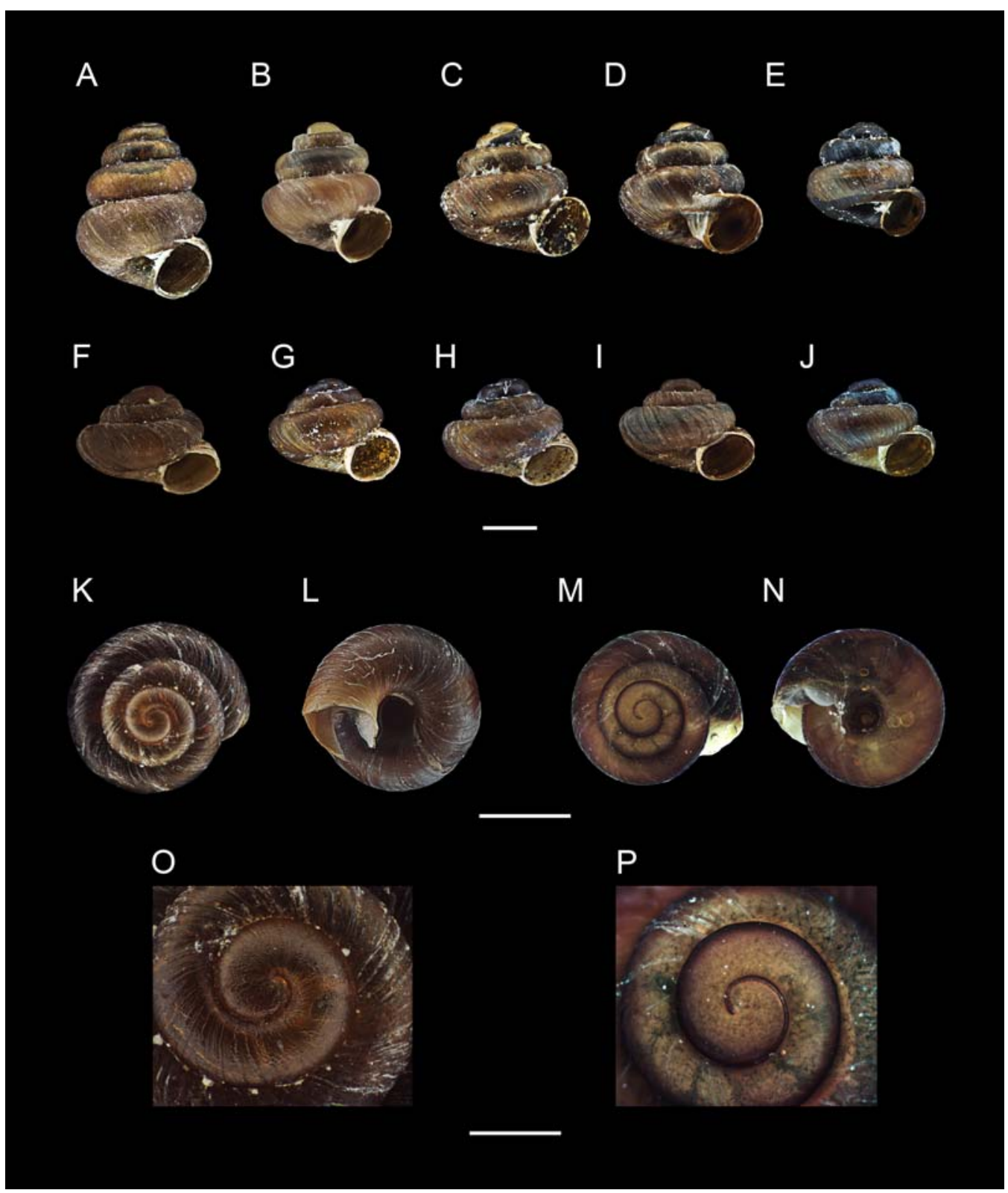

Fig. 5. Shells of Pyramidula jaenensis. A — Ubeda, Jaén, Spain; B-C - Patones, Madrid, Spain; D-E Pontón de la Oliva, Madrid, Spain; K - apical view of the shell; L - umbilical view; O - details of the protoconch. Shells of Pyramidula rupestris. F-J - Jaraba, Aragón, Spain; M - apical view of the shell; $\mathrm{N}$ - umbilical view; $\mathrm{P}-$ details of the protoconch. Scale bars: A-N $-1 \mathrm{~mm} ; \mathrm{O}-\mathrm{P}-500 \mu \mathrm{m}$.

Рис. 5. Раковины Pyramidula jaenensis. А - Убеда, Хаэн, Испания; В-C - Патонес, Мадрид, Испания; D-E - Понтон де ла Олива, Мадрид, Испания; K - апикальный вид раковины; L — вид со стороны пупка раковины; О — детали строения протоконха. Раковины Pyramidula rupestris. F-J Хараба, Арагон, Испания; М - апикальный вид раковины; $\mathrm{N}$ - вид со стороны пупка раковины; $\mathrm{P}$ - детали строения протоконха. Масштабный штрих: A-N -1 мм; O-P - 500 мкм. 


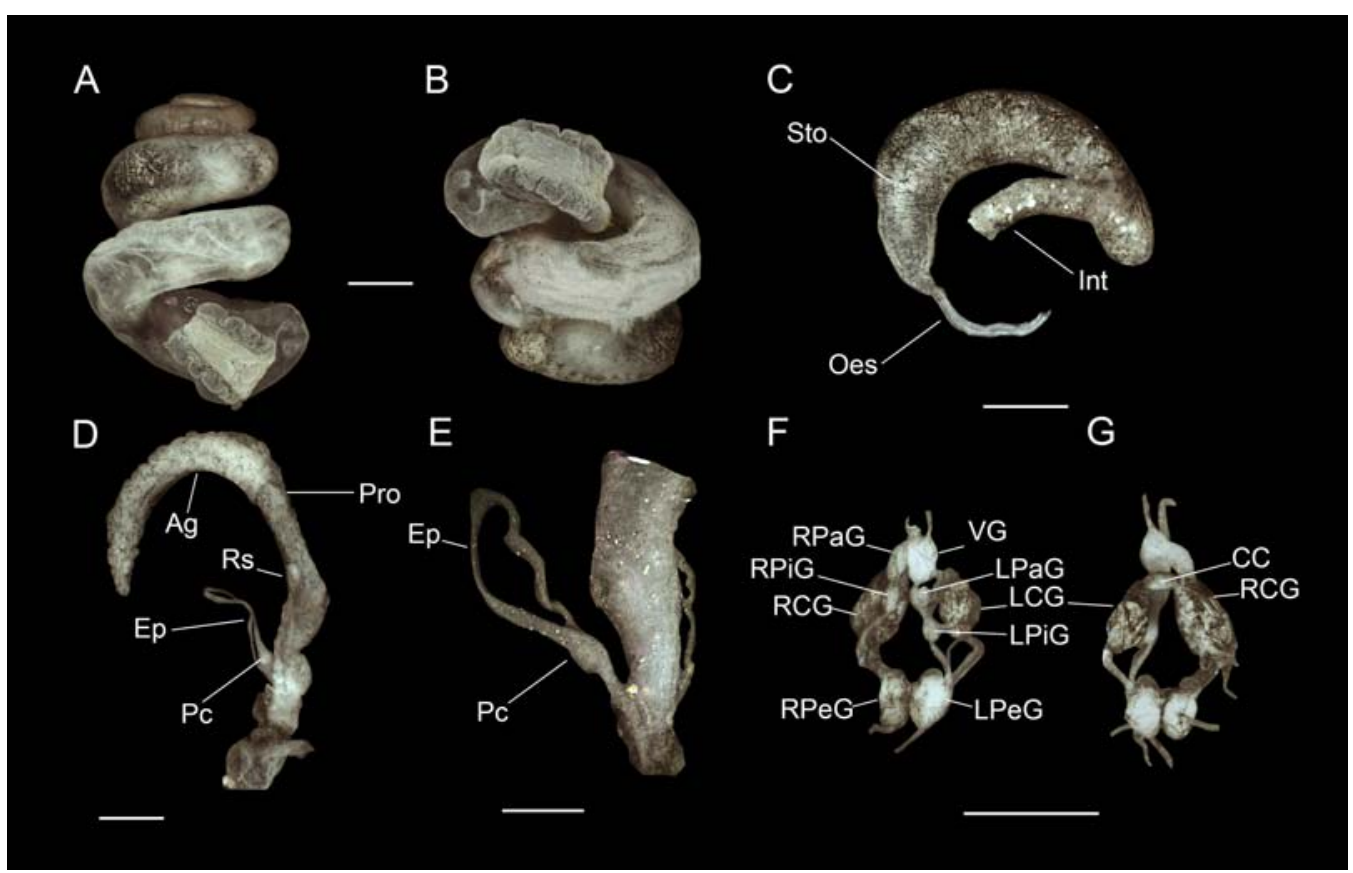

Fig. 6. Anatomy of Pyramidula jaenensis from Patones, Madrid, Spain. A-B - complete animal, without the shell, showing the buccal tentacles (B); C — digestive system; D — genitalia with the uterus empty; E details of the penial caecum and epiphallus; F — ventral view of the oesophageal neural ring; $\mathrm{G}$ - dorsal view of the oesophageal neural ring. Scale bars: A, D, F-G $-500 \mu \mathrm{m}$; E - $200 \mu \mathrm{m}$.

Abbreviations: Ag — albumen gland; CC — cerebral commissure; CG - cerebral ganglia; Ep — epiphallus; Int — intestine; $\mathrm{PaG}$ - parietal ganglia; Pc — penial caecum; PeG — pedal ganglia; PiG — pleural ganglia; Oes — oesophagus; Pro - prostate; Rs - reservoir of spermatheca; Sto — stomach; VG — visceral ganglion;

Рис. 6. Анатомия Pyramidula jaenensis из Патонеса, Мадрид, Испания. А-B - целое животное без раковины с буккальными щупальцами (B); C — пищеварительная система; D — половая система с пустой маткой; E - детали строения пениального выроста и эпифаллоса; F — нервное кольцо пищевода, вид с вентральной стороны; $\mathrm{G}$ - нервное кольцо пищевода, вид с дорсальной стороны. Масштабный штрих: A, D, F-G - 500 мкм; E - 200 мкм.

Сокращения: Ag — белковая железа; CC - церебральная коммисура; CG — церебральный ганглий; Ер эпифаллус; Int — кишечник; PaG — париетальный ганглий; Pc — пениальный вырост; PeG — педальный ганглий; PiG — плевральный ганглий; Oes — пищевод; Pro — простата; Rs — peзервуар сперматеки; Sto желудок; VG — висцеральный ганглий.

V-shaped, with a rounded cusp; lateral teeth bicuspid; ectocone small triangular, endocone large, V-shaped with a rounded cusp; marginal teeth range from $6-11$. Oesophagus long and narrow, connecting to the proximal part of the stomach; stomach cylindrical, 4-5 times longer than wide (Fig. 6C), darkly pigmented. Oesophageal neural ring composed by nine ganglia interconnected by short connectives; darkly pigmented; cerebral commissure short, its length is less than the width of the cerebral ganglia or about the same size. Left parietal ganglion separated from the pleural ganglion and visceral ganglion by short connectives. Right parietal ganglion separated by a short connective from the right pleural ganglion and fused to the visceral ganglion (Fig. 6F-G).

DISTRIBUTION: According to Razkin et al. (2017) the species occurs in Southwestern Europe and North Africa, these areas correspond mainly to the Iberian Peninsula, Southern France and Apennine peninsula (Fig. 8). In this study, we extend the distribution area of the species to the central zone of the Iberian Peninsula. 


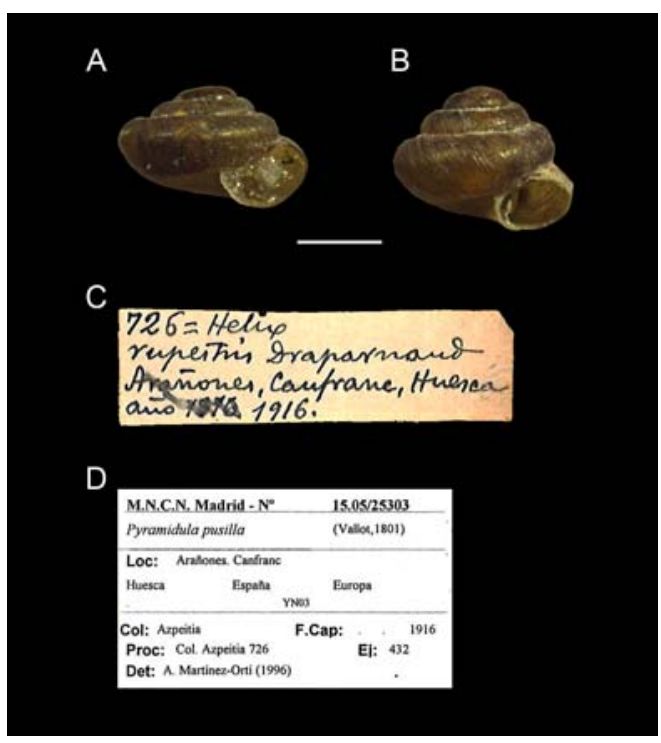

Fig. 7. Pyramidula rupestris, A-B - shells from Arañones, Aragón; $\mathrm{C}$ - original label according to the collector Florentino Azpeitia Moros; D - current label with a posterior shift to Pyramidula pusilla by Alberto Martínez-Ortí.

Рис. 7. Pyramidula rupestris, A-B - раковины из Араньенес, Арагон; C - оригинальная этикетка согласно сборщикуФлорентину Азпетиа Моросу; D - нынешняя этикетка с последующим исправлением видовой идентификации на Pyramidula pusilla по Альберто Мартинез-Орти.
REMARKS: This species is different in shape from the rest of the species here studied, this will be further discussed. According to the radula, we have found differences between $P$. jaenensis and $P$. rupestris. Bowell (1915) cited for $P$. rupestris a radular formula 11-7(8) -1-7(8) 11, while we have found on $P$. jaenensis half number of the marginal teeth (6). Also, according to the sculpture of the protoconch we have found differences between both species. We found a rugose sculpture changing to moderate striated in $P$. jaenensis while the sculpture in $P$. rupestris is smooth with a lesser prominent transition to the striated sculpture (Fig. 5 O, P). Further studies are needed, fathoming out the morphological characters here studied to find suitable ways to delimit the species of this genus in the Iberian Peninsula.

ECOLOGY: This species is widely distributed by all carbonated areas of the Iberian Peninsula, being the availability of carbonated rocks conditioning the presence of this species. It occurs in calcareous walls occasionally sympatric with other Pyramidula species, being found often also inhabiting sympatrically with species of the family Chondrinidae Steenberg, 1925, in this case, we find it occurring with Granopupa granum (Draparnaud, 1801).

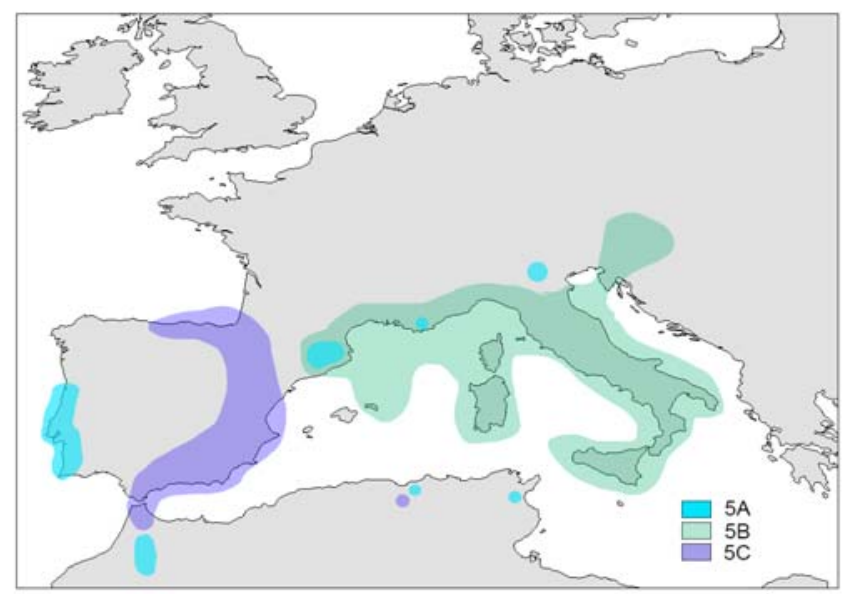

Fig. 8. Distribution of Pyramidula jaenensis according to Razkin et al. (2017). Groups correspond to the phylogenetic clades obtained by these authors.

Рис. 8. Распространение Pyramidula jaenensis согласно Razkin et al. (2017). Группы соответствуют филогенетическим кладам, полученным этими авторами. 


\section{Discussion}

Our molecular analysis confirmed the taxonomical position of our new records within $P$. jaenensis. Also, when examining morphological data these populations presented values in shell size very close to the typical $P$. jaenensis values described by Martínez-Ortí et al. (2007). Although Almodovar et al. (1996) cited the presence of Pyramidula in Madrid, we think that this is a misidentified sample. Those authors pointed out that they found the species occurring under nearby poplar leaf litter on the margins of the Tagus river and in the holes of limestone on the edge of a rain-fed crop. This habitat does not correspond with what has been observed in Pyramidula. Instead, we think it could be a juvenile of any other species of Pupillidae W. Turton, 1831, that tends to have a more similar habitat to the one described by those authors.

Our comparison with $P$. rupestris, according to the geometric morphometric analysis, revealed also significant differences between both species (Fig. 4). The PCA delimited $P$. jaenensis and $P$. rupestris as separated welldefined clusters which presented statistical significance according to the PERMANOVA with a $p$-value $=0.003$. The Thin-Plate Spline graph (Fig. 4) also depicted high differences in the patterns of shell shape. While P. jaenensis presented an expansion factor to the apex, $P$. rupestris presented the same expansion but more to the columellar axis in the first whorl and the aperture. This method could reveal morphological differences between closely related species or cryptic species that for bared eye could pass unnoticed (Stone, 1998; Kirchner et al., 2016; Vergara et al., 2017).

When we compared $P$. rupestris with $P$. pusilla, we found that the geometric morphometric analysis clustered together both species with overlapping (Fig. 4). Although the PERMANOVA revealed significant differences ( $p$ value $=0.012$ ), this could be a consequence of the lack of homogeneity on the dataset (PERMDISP, $p$-value $=0.001$ ) as suggested by Anderson (2001); Anderson et al. (2006) and Ander- son (2005).

So far, we did not confirm previously by molecular methods the species $P$. pusilla because it is a dry collection material. Consequently, we assume it is more likely to be a case of samples misidentified. This lot (MNCN 15.15/ 25033) was initially identified by the collector as $P$. rupestris, later on another researcher changed it to $P$. pusilla (Fig. 7) Now our analyses revealed that when analysing the shells there is no difference between what occurs in Arañones, Aragón and our samples identified as $P$. rupestris.

Most of the time we assumed that museum samples are identified perfectly. On the contrary, in many cases this assumption is not warranted (Elphick, 2008). Proper species identification can get stuck by morphology as in Pyramidula (Razkin et al., 2016, 2017) and also by observer-level factors such as expertise (Sauer et al. 1994). It is common to find examples of the same problem in literature (e.g., Shea et al., 2011, Barbanera et al., 2016, Kitchener et al., 2020) and this case opens the opportunity of new questions about both species that could be addressed in future research.

As species of Pyramidula had been mentioned to occur sympatrically (Gittenberger, Bank, 1996), we found in geometric morphometrics a consistent tool for species delimitation through shell shape (Cardini, Elton, 2011; Rohlf, 2002). This kind of analysis along with the use of other sources of information such as DNA, morphology, ecology or ethology will achieve the goal of integrative taxonomy (Dayrat, 2005).

Preceding studies of this genus have focused only on one source of information. While Gittenberger \& Bank (1996) and Martínez-Ortí et al. (2007) focused strictly on conchological data, the studies of Razkin et al., (2017) were focused more on molecular data. This introduced a valuable framework as they defined molecularly the species. Nevertheless, the species boundaries in some cases were inconclusive as they delimited species based only on shell dimensions.

If we take the idea that Pyramidula is a complex of cryptic species as suggested by 
Martínez-Ortí et al. (2007) and Razkin et al. (2017), it would be very interesting to review what we understand by P. jaenensis. According to Razkin et al. (2017), their molecular species delimitation showed two well-supported clades (5A and 5C) and one unsupported group (5B). However, when analysing the distribution of the populations that were analysed, it shows nearly no spatial overlap between groups (Fig. 8). This leads us to wonder if $P$. jaenensis is occurring in southern Europe by the Mediterranean slope from Portugal to the Balkans, or if we have considered three biological entities as just one. The answer to this question requires further studies where morphology is analysed in-depth, using integrative taxonomy.

Acknowledgements. This work was supported by the Spanish Ministry of Economy and Competitivity by the project Fauna Ibérica XII PGC2018-095851-B-C61, which provided with the use of the laboratory equipment and financial support for sequencing the samples; the postdoctoral contract of the University Rey Juan Carlos (URJC) and the Autonomous Community of Madrid (CAM) (contract identifier number: E-28-2021-0749641), linked to the REMEDINAL TE-CM project entitled "Conocimiento científico para avanzar hacia la consecución de los Objetivos de Desarrollo Sostenible: una ecología translacional es necesaria" (reference S2018/EMT-4338) linked to Antonio Alberto Rodríguez Sousa; the PTA2016-13213-I fellowship granted to Fernando García Guerrero.

\section{References}

Allas R.B., Barroso M.A.D., Rodríguez R.P. 2001. Mapa de degradación de los suelos de la Comunidad de Madrid. Dirección General de Promoción y Disciplina Ambiental.

Almodovar A., Mufioz B., Refoyo P., Parejo, C. 1996. Gasterópodos terrestres testaceos (Gastropoda, Pulmonata, Stylommatophora) del Sureste de la Comunidad de Madrid // Boletín de la Real Sociedad Española de Historia Natural (Sección Biológica). Vol.92. No.1-4. P.127-138.

Anderson M.J. 2001. Permutation tests for univariate or multivariate analysis of variance and regression // Canadian Journal of Fisheries and Aquatic Sciences. Vol.58. No.3. P.626-639.
Anderson M.J. 2005. Permutational multivariate analysis of variance // Department of Statistics, University of Auckland, Auckland. Vol.26. P.32-46.

Anderson M.J., Ellingsen K.E., McArdle B.H.. 2006. Multivariate dispersion as a measure of beta diversity // Ecology Letters. Vol.9. No.6. P.683-693.

Anderson M.J. 2014. Permutational multivariate analysis of variance (PERMANOVA) // Wiley statsref: statistics reference online. P.1-15.

Anderson M.J., Walsh D.C. 2013. PERMANOVA, ANOSIM, and the Mantel test in the face of heterogeneous dispersions: what null hypothesis are you testing? // Ecological monographs. Vol.83. No.4. P.557-574.

Aparicio M.T. 2006. Catálogo bibliográfico de los gasterópodos terrestres de la Comunidad de Madrid // Graellsia: revista de zoología. Vol.62. No.Extra. P.99103.

Barbanera F., Moretti B., Guerrini M., Al-Sheikhly O.F., Forcina G. 2016. Investigation of ancient DNA to enhance natural history museum collections: misidentification of smooth-coated otter (Lutrogale perspicillata) specimens across multiple museums // Belgian Journal of Zoology. Vol.146. No.2. P.101-112.

Bowell E. 1915. Note on the radula of Pyramidula rupestris (Drap.) // Journal of Conchology. Vol.14. P.290291.

Cardini A., Elton S. 2011. GeMBiD, a Geometric Morphometric Approach to the Study of Biological Diversity: An Example Study of the Red Colobus (Procolobus [Piliocolobus]) Species Complex // International Journal of Primatology. Vol.32. No.2. P.377-389.

Charif D., Lobry J.R. 2007. SeqinR 1.0-2: a contributed package to the $\mathrm{R}$ project for statistical computing devoted to biological sequences retrieval and analysis // Structural approaches to sequence evolution. Springer. P.207-232.

Clark K., Karsch-Mizrachi I., Lipman D.J., Ostell J., Sayers E.W. 2016. GenBank // Nucleic acids research. Vol.44. No.D1. P.67-72.

Clessin S. 1882. Neue Arten von S. Clessin // Malakozoologische Blätter: Als Fortsetzung der Zeitschrift für Malakozoologie. N.F. Bd.15. S.187-193.

Core-Team R. 2017. R: A language and environment for statistical computing. R Foundation for Statistical Computing, Vienna, Austria.

Cracraft J. 1983. Species concepts and speciation analysis // Current Ornithology. Springer. P.159-187

Dayrat B. 2005. Towards integrative taxonomy // Biological journal of the Linnean society. Vol.85. No.3. P.407-417.

Eldredge N., Cracraft J. 1980. Phylogenetic patterns and the evolutinary process // Method and Theory in Comparative Biology. Vol.8. P.1-349.

Elphick C. S. 2008. How you count counts: the importance of methods research in applied ecology // Journal of Applied Ecology. Vol.45. No.5. P.1313-1320.

Folmer O., Black M.B., Hoeh W.R., Lutz R.A., Vrijenhoek R. 1994. DNA primers for amplification of mitochondrial cytochrome c oxidase subunit I from diverse metazoan invertebrates // Molecular marine biology and biotechnology. Vol.3. No.5. P.294-299. 
Kitchener A.C., Machado F.A., Hayssen V., Moehlman P.D., Viranta S. 2020. Consequences of the misidentification of museum specimens: the taxonomic status of Canis lupaster soudanicus // Journal of Mammalogy. Vol.101. No.4. P.1148-1150.

Gittenberger E., Bank R. 1996. A new start in Pyramidula (Gastropoda Pulmonata: Pyramidulidae) // Bacteria. Vol.60. No.1/3. P.71-78.

Gower J.C. 1975. Generalized procrustes analysis // Psychometrika. Vol.40. No.1. P.33-51.

Hammer Ø., Harper D., Ryan P. 2020. PAST-PAlaeontological STatistics, ver. 4.0. // University of Oslo, Oslo. P.1-31.

Hotopp, K.P. 2002. Land snails and soil calcium in central Appalachian Mountain forest // Southeastern Naturalist. Vol.1. No.1. P.27-44.

Huelsenbeck J.P., Ronquist F. 2001. MRBAYES: Bayesian inference of phylogenetic trees // Bioinformatics. Vol.17. No.8. P.754-755.

Jolliffe I. 2002. Principal component analysis. Wiley Online Library.

Juřičková L., Horsák M., Cameron R., Hylander K., Míkovcová A., Hlaváč J.Č., Rohovec J. 2008. Land snail distribution patterns within a site: the role of different calcium sources // European Journal of Soil Biology. Vol.44. No.2. P.172-179.

Karampaglidis T., Benito-Calvo A., Pérez-González A. 2015. Geomorphology of the Lozoya river drainage basin area (Community of Madrid, Spanish Central System) // Journal of Maps. Vol.11. No.2. P.342-353.

Kirchner S., Harl J., Kruckenhauser L., Duda M., Sattmann H., Haring E. 2016. Phylogeography and systematics of Pyramidula (Pulmonata: Pyramidulidae) in the eastern Alps: still a taxonomic challenge // Journal of Molluscan Studies. Vol.82. No.1. P.110 121.

Kumar S., Stecher G., Tamura K. 2016. MEGA7: Molecular Evolutionary Genetics Analysis version 7.0 for bigger datasets // Molecular biology and evolution. Vol.33. No.7. P.1870-1874.

Martínez-Ortí A., Gómez-Moliner B., Prieto C. 2007. El género Pyramidula Fitzinger 1833 (Gastropoda, Pulmonata) en la Península Ibérica // Iberus. Vol.25. No.1. P.77-87.

Miller M.A., Pfeiffer W., Schwartz T. 2010. Creating the CIPRES Science Gateway for inference of large phylogenetic trees. In: 2010 gateway computing environments workshop (GCE)). P.1-8.

Mylonas M. 1982. New data on the taxonomy and distribution of Pyramidula rupestris chorismenostoma (Blanc)(Gastropoda, Pulmonata) // Malacologia. Vol.22. No.1-2. P.439-440.

Oksanen J., Blanchet F.G., Kindt R., Legendre P., Minchin P.R., O'hara R., Simpson G.L., Solymos P., Stevens M.H.H., Wagner H. 2013. Package ‘vegan'. Community ecology package, version 2.0. P.1-295.

Ortiz de Zárate A. 1961. Moluscos terrestres recogidos en la provincia de Huelva // Boletín de la Real Sociedad Española de Historia Natural (Sección Biológica). Vol.59. P.169-190.
Paradis E., Schliep K. 2018. ape 5.0: an environment for modern phylogenetics and evolutionary analyses in $\mathrm{R}$ // Bioinformatics. Vol.35. No.3. P.526-528.

Rambaut A. 2012. FigTree v1.4.

Razkin O., Gómez-Moliner B.J., Vardinoyannis K., Martínez-Ortí A., Madeira M.J. 2017. Species delimitation for cryptic species complexes: case study of Pyramidula (Gastropoda, Pulmonata) // Zoologica Scripta. Vol.46. P.55-72.

Razkin O., Sonet G., Breugelmans K., Madeira M.J., Gómez-Moliner B.J., Backeljau T. 2016. Species limits, interspecific hybridization and phylogeny in the cryptic land snail complex Pyramidula: the power of RADseq data // Molecular Phylogenetics and Evolution. Vol.101. P.267-278.

Rohlf F. 2006. tpsDig, version 2.10. Department of Ecology and Evolution, State University of New York, Stony Brook.

Rohlf F.J. 2002. Geometric morphometrics and phylogeny // Morphology, shape and phylogeny. Vol.64. P.175193.

Ronquist F., Huelsenbeck J.P. 2003. MrBayes 3: Bayesian phylogenetic inference under mixed models // Bioinformatics. Vol.9. No.12. P.1572-1574.

Sauer J.R., Peterjohn B.G., Link W.A. 1994. Observer differences in the North American breeding bird survey // The Auk. Vol.111. No.1. P.50-62.

Schileyko A. 1998. Treatise on Recent Terrestrial Pulmonate Molluscs, Part 1. Achatinellidae, Amastridae, Orculidae, Strobilopsidae, Spelaeodiscidae, Valloniidae, Cochlicopidae, Pupillidae, Chondrinidae, Pyramidulidae // Ruthenica. Suppl.2. P.1-127.

Schileyko A.A., Balashov I. 2012. Pyramidula kuznetsovi sp. nov. a new species of land molluscs from Nepal (Pulmonata, Pyramidulidae) // Ruthenica. Vol.22. No.1. P.41-45.

Shea C.P., Peterson J.T., Wisniewski J.M., Johnson N.A.. 2011. Misidentification of freshwater mussel species (Bivalvia: Unionidae): contributing factors, management implications, and potential solutions // Journal of the North American Benthological Society. Vol.30. No.2. P.446-458.

Stamatakis A. 2014. RAxML version 8: a tool for phylogenetic analysis and post-analysis of large phylogenies // Bioinformatics. Vol.30. No.9. P.1312-1313.

Stone J. 1998. Landmark based thin plate spline relative warp analysis of gastropod shells // Systematic Biology. Vol.47. No.2. P.254-263.

Tavaré S. 1986. Some probabilistic and statistical problems in the analysis of DNA sequences // Lectures on Mathematics in the Life Sciences. Vol.17. P.57-86.

Vergara D., Fuentes J.A., Stoy K.S., Lively C.M. 2017. Evaluating shell variation across different populations of a freshwater snail // Molluscan Research. Vol.37. No.2. P.120-132.

Welter-Schultes F., Williams M. 1999. History, island area and habitat availability determine land snail species richness of Aegean islands // Journal of Biogeography. Vol.26. P.239-249.

Wilke T., Davis G.M., Cui-E C., Xiao-Nung Z., Peng Z.X., 
Yi Z., Spolsky C.M. 2000. Oncomelania hupensis (Gastropoda: Rissooidea) in eastern China: molecular phylogeny, population structure, and ecology // Acta Tropica. Vol.77. P.215-227.

Winter D.J. 2017. rentrez: an R package for the NCBI eUtils API // The R Journal. Vol.9. P.520-526.

Yagüe A.G. 1979. La geología de Madrid // Revista de Obras Públicas. Vol.3109. P.1043-1055.

Responsible editor E.N. Temereva 